\title{
PENGELOLAAN BADAN USAHA MILIK DESA (BUMDES) TEPULE DESA TUDUNGANO KECAMATAN SAWA KABUPATEN KONAWE UTARA
}

\author{
Beni Hasrianto, Syahbuddin, Wa Ode Reni \\ Jurusan Pendidikan Pancasila dan Kewarganegaraan \\ Fakultas Keguruan dan Ilmu Pendidikan \\ Universitas Halu Oleo \\ Email: benihasrianto@gmail.com syahbuddin@gmail.com, reni@gmail.com
}

\begin{abstract}
Abstrak: Masalah penelitian ini adalah: 1) Bagaimanakah pengelolaan Badan Usaha Milik Desa (Bumdes) Tepule Desa Tudungano Kecamatan Sawa Kabupaten Konawe Utara; 2) Faktor penghambat apa saja yang dihadapi badan usaha milik desa (Bumdes) dalam pengelolaan Bumdes Tepule Desa Tudungano Kecamatan Sawa Kabupaten Konawe Utara; dan 3) Upaya apa saja yang dilakukan pengurus badan usaha milik desa (Bumdes) dalam mengatasi hambatan yang dihadapi Badan Usaha Milik Desa (Bumdes) Tepule Desa Tudungano Kecamatan Sawa Kabupaten Konawe Utara.Tujuan penelitian ini adalah: 1) Untuk mengetahui bagaimanakah pengelolaan Badan Usaha Milik Desa (Bumdes) Tepule Desa Tudungano Kecamatan Sawa Kabupaten Konawe Utara; 2) Untuk mengetahui Faktor penghambat apa saja yang dihadapi badan usaha milik desa (Bumdes) dalam pengelolaan Bumdes Tepule Desa Tudungano Kecamatan Sawa Kabupaten Konawe Utara; dan 3) Untuk mengetahui Upaya apa saja yang dilakukan pengurus badan usaha milik desa (Bumdes) dalam mengatasi hambatan yang dihadapi Badan Usaha Milik Desa (Bumdes) Tepule Desa Tudungano Kecamatan Sawa Kabupaten Konawe Utara, dengan menggunakan jenis penelitian kualitatif yaitu mendeskripsikan data dan informasi hasil penelitian.Hasil penelitian menunjukan bahwa badan usaha milik desa mempunyai dua unit usaha yaitu penambangan batu gunung, dan usaha sewa barang yaitu kursi, yang dijalanakan mulai dari tahun terbentuknya Bumdes Tepule yaitu tahun 2016 yang terbentuk berdasarkan hasil musyawarah desa, akan tetapi kesenjagan yang terjadi di Badan usaha milik Desa Tudungano Kecamatan Sawa Kabupaten Konawe Utara antara dimulai dari pembentukan unit-unit usaha yang tidak melibatkan masyarakat sebagai objek Bumdes ini, sumber daya manusia pengurus Bumdes yang kurang, transparansi anggaran kepada masyarakat termasuk pemerintah desa tidak dilakukan, terjadinya kerugian bumdes diakibatkan karena tidak adanya pemasaran dari hasil penambangan batu gunung sebagai program utama Bumdes Tepule, tidak terjalinnya komunikasi yang baik antar pengurus Bumdes, pemerintah dan pengurus Bumdes.Kesimpulan dari penelitian ini adalah Faktor penghambat Bumdes Tepule di Desa Tudungano Kecamatan Sawa Kabupaten Konawe Utara, upaya telah dilakukan pemerintah bersama masyarakat.
\end{abstract}

\section{Kata Kunci: Bumdes, Peningkatan dan Ekonomi}

\section{PENDAHULUAN}

Pembangunan Nasional bertujuan untuk mewujudkan masyarakat adil dan makmur yang merata berdasarkan Pancasila dan Undang-Undang Dasar Republik Indonesia 1945 dalam wadah Negara Kesatuan Republik Indonesia yang merdeka, bersatu, dan berkedaulatan rakyat. Titik berat pembangunan diletakkan pada bidang ekonomi yang merupakan penggerak utama pembangunan seiring dengan kualitas sumberdaya manusia dan didorong secara saling memperkuat, saling terkait dan terpadu dengan pembangunan bidang-bidang lainnya yang dilaksanakan selaras, 
serasi dan seimbang guna keberhasilan pembangunan di bidang ekonomi dalam rangka mencapai tujuan dan sasaran pembangunan nasional. Bertitik tolak pada pembangunan tersebut, maka pemerintah dan rakyat Indonesia mempunyai kewajiban untuk menggali, mengolah dan membina potensi yang ada tersebut guna mencapai masyarakat yang adil dan makmur sesuai dengan Undang Undang Dasar 1945.

Era mendukung daerah untuk lebih memperhatikan nilai-nilai yang berguna untuk mencapai kesejahteraan masyarakatnya serta menciptakan kemandirian daerah guna meningkatkan pendapatan Asli Desa dan peningkatan kehidupan yang lebih baik dalam bidang ekonomi,sosial maupun politik. Otonomi yang memberikan kewenangan sepenuhnya kepada daerah untuk menjalankan pemerintahan yang mandiri dan kreatif dalam meningkatkan kesejahteraan masyarakat di daerah maupun masyaraskat yang ada didesa. Dalam Undang-Undang No.6 Tahun 2014 Tentang Desa, Pasal 1 ayat 1 di sebutkan bahwa Desa adalah Desa dan Desa adat atau yang disebut dengan nama lain, selanjutnya disebut desa, adalah kesatuan masyarakat hukum yang memiliki batas wilayah yang berwenang untuk mengatur dan mengurus urusan pemerintahan,kepentingan masyarakat setempat berdasarkan prakarsa masyarakat, hak asal usul, dan/atau hak tradisional yang diakui dan dihormati dalam sistem pemerintahan negara Kesatuan Repulik Indonesia.

Bumdes adalah badan usaha yang seluruh atau sebagian besar modalnya dimilikioleh Desa melalui penyertaan secara langsung yang berasal dari kekayaan Desa yang dipisahkan guna mengelola aset, jasa pelayanan, dan usaha lain demi kesejateraan masyarakat. Peraturan Desa Tudungano No 6 tahun 2014 Badan Usaha Milik Desa,selanjutnya disebut Bumdes, adalah badan usaha yang seluruh atau sebagian besar modalnya dimiliki oleh Desa melalui penyertaan secara langsung yang berasal dari kekayaan Desa yang dipisahkan guna mengelola aset, jasa pelayanan, dan usaha lainnya untuk sebesar-besarnya kesejahteraan masyarakat Desa.

Desa adalah kesatuan masyarakat hukum yang memiliki batas-batas wilayah yang berwenang untuk mengatur dan mengurus kepentingan masyarakat setempat, berdasarkan asal-usul dan adat istiadat setempat yang diakui atau dihormati dalam sistem pemerintahan Negara Kesatua Repulik Indonesia (Undang-Undang No.23 Tahun 2014). Menurut Widjajadalam Wiwin (2017) yang mengemukakan mengenai pengertian Desa adalah suatu kesatuan masyarakat hukum yang mempunyai susunan asli berdasarkan hak asal-usul yang bersifat istimewa dimana landasan pemikirannya dalam mengenai pemerintahan Desa adalah keanekaragaman, partisipasi, otonomi asli, demokratisasi, dan pemberdayaan masyarakat. Menurut Maryuni dalamSamadi, dkk.,(2018) bahwa Bumdes adalah lembaga usaha desa yang dikelola oleh masyarakat dan pemerintahan desa dalam upaya memperkuat perekonomian desa dan membangun kerekatan social masyarakat yang dibentuk berdasarkan kebutuhan dan potensi desa.

Ciri utama yang membedakan Bumdes dengan lembaga ekonomi komersial adalah sebagai berikut:

1. Modal usaha bersumber dari desa $(51 \%)$ dan dari masyarakat $(49 \%)$ melalui penyertaan modal (saham atau andil).

2. Badan usaha ini dimiliki oleh desa dan dikelola secara bersama.

3. Dijalankan dengan berdasarkan asas kekeluargaan dan kegotongroyongan serta berakar dari tata nilai yang berkembang dan hidup dimasyarakat (local wisdom). 
4. Bidang usaha yang dijalankan berdasarkan pada pengembangan potensi desa secara umum dan hasil informasi pasar yang menopang kehidupan ekonomi masyarakat.

5. Tenaga kerja yang diberdayakan dalam Bumdes merupakan tenaga kerja potensial yang ada didesa.

6. Keuntungan yang diperoleh ditunjukan untuk meningkatkan kesejahteraan masyarakat desa dan penyerta modal.

7. Pengambil keputusan dan penyelesaian masalah dilakukan melalui musyawarah desa.

8. Peraturan-peraturan Bumdes dijalankan sebagai kebijakan desa (village policy).

9. Difasilitasi oleh pemerintah provinsi, pemerintah Kabupaten, dan pemerintah desa.

10. Pelaksaan kegiatan Bumdes diawasi secara bersama (pemerintah desa, BPD, anggota). (Samadi, dkk., 2018: 10).

Secara konseptual pemberdayaan Bumdes tidak jauh berbeda dengan konsepkonsep pemberdayaan masyarakat yang sudah banyak dikenal dewasa ini, misalnya sebagai upaya memperkuat unsur-unsur keberdayaan untuk meningkatkan harkat dan martabat lapisan masyarakat yang berada dalam kondisi yang tidak mampu dengan mengendalikan kekuatan sendiri sehingga dapat keluar dari perangkap kemiskinan dan keterbelakangan, atau proses memampukan dan memandirikan masyarakat konsep pemberdayaan Bumdes merupakan pemberdayaan potensi-potensi pembangunan yang ada didesa yang bersumber dari, oleh, dan untuk masyarakat atau dengan kata lain dilaksanakan secara partisipatif (Kurniawan, 2016: 15).

Menurut Solekhan dalam Sitepu, (2018) besarnya peranan badan usaha miik desa (Bumdes) dalam memberikan alternativ pada beberapa program pendampingan maupun hibah, maka perlu adanya konsep pengeloaan yang baik meliputi : (1) pengelolaan bumdes harus secara terbuka dan dapat diketahui oleh masyarakat. (2) pengelolaan bumdes harus dapat dipertanggung jawabkan kepada masyarakat desa dengan mngikuti kaidah dan peraturan yang berlaku. (3) masyarakat desa twerlibat secara aktif dalam proses perencanaan, pelaksaan, pengawasan. (4) dan pengelolaan bumdes harus memberikan hasil dan manfaat untuk warga masyarakat secara berkelanjutan.

Menurut peraturan menteri dalam negri No 39 Tahun 2010 Tentang Bumdes pasal 5 tentang syarat terbentuknya bumdes yaitu:Atas inisiatif pemerintah desa dan masyasarakat desa melalui musyawarah desa, Adanya potensi usaha ekonomi masyarakat, Sesuai dengan kebutuhan masyarakat terutama kebutuhan poko masyarakat, Tersediaanya sumber daya desa yang belum dimanfaatkan secara optimal terutama kekayaan desa, Tersedianya sumber daya manusia yang mampu mengelola badan usaha sebagai aset penggerak ekonomi masyrakat desa, Adanya unit-unit usaha masyarakat yang merupakan kegiatan ekonomi warga masyarakat yang dikelola secara parsial dan kurang terakomondasi dan Untuk meningkatkan pendapatan masyrakat desa maupun pendapatan asli desa (Peraturan mentri dalam negri No 39 tahun 2010).

Pembangunan desa merupakan bagian dari pembanguna nasional dan pembanguna desa ini memiliki arti dan peranan yang penting dalam mencapai tujuan nasional, karena desa beserta masyarakatnya merupakan basis dan ekonomi, politik, social budaya, pertahanan keamanan.Kewajiban pemerintah adalah menyediakan 
sarana dan prasarana sedangkan selebihnya disandarkan kepada kemampuan masyarakat itu sendiri. Proses pembanguna desa merupakan mekanisme dari keinginan masyarakat yang dipadukan dengan masyarakat (Ferdianto, 2016).

Perpaduan tersebut menentukan keberhasilan mekanisme pembangunan desa adalah merupakan perpaduan yang serasi antara kegiatan partisipasi masyarakat dalam pihak dan kegiatan pemerintah disatu pihak.Bahwa pada hakikatnya pembanguna desa dilakukan oleh masyarakat itu sendiri.Sedangkan pemerintah memberikan bimbingan, bantuan, pembinaan, dan pengawasan.Pembanguna desa adalah pembanguan berbasis pedesaan dengan mengedapankan kearifan lokal kawasan pedesaan yang mencakup struktur demografi masyarakat, karakteristik social budaya, karakterisitik fisik/geografis, pola kegiatan usaha pertanian, pola keterkaitan ekonomi desa-kota, sektor kelembagaan desa, dan karakterisitik kawasan pemukiman(Noviratullah, 2018).

\section{METODE PENELITIAN}

\section{Tempat dan Waktu Penelitian}

Penelitian ini dilaksanakan pada Badan Usaha Milik Desa (Bumdes) di Desa Tudungano, Kecamatan Sawa, Kabupaten Konawe Utara. Pemilihan lokasi ini didasarkan pada pertimbangan bahwa pengelolaan badan usaha milik desa di desa Tudungano Kecamatan Sawa Kabupaten Konawe Utara tidak memberikan konstribusi yang baik. Penelitian ini dilaksanakan pada bulan oktober 2018 sampai dengan bulan november 2018.

\section{Jenis Penelitian}

Jenis penelitian yang digunakan adalah penelitian kualitatif, yaitu mendeskripsikan data dan informasi dari hasil penelitian secara langsung yang sesuai dengan masalah penelitian ini dan memberikan gambaran atau penjelasan tentang pelaksanaan peran Badan Usaha Milik Desa (Bumdes) dalam meningkatkan perekonomian di Desa Tudungano Kecamatan Sawa Kabupaten Konawe Utara.

\section{Subjek Penelitian}

Subjek dalam penelitian ini terdiri dari responden dan informan yang terdiri dari: Responden terdiri dari penasehat Bumdes Tepule atau kepala Desa Tudungano, Direksi Bumdes Tepule, sekretaris Bumdes Tepule. Informan penelitian ini terdiri empat masyarakat Desa Tudungano, ketua pengawas Bumdes Tepule, satu ibu rumah tangga, Tasmin selaku masyarakat Desa Tudungano, sekretaris Desa Tudungano.

\section{Teknik Pengumpulan Data}

Teknik pengumpulan data dalam penelitian ini digunakan beberapa metode pengumpulan data yaitu, wawancara dan dokumentasi. Teknik analisis data yang diperoleh dianalisis dengan kualitatif model Miles dan Huberman.

\section{HASIL DAN PEMBAHASAN Pengelolaan Bumdes Tepule}

Bumdes suatu lembaga ekonomi yang modal usahanya dibangun atas inisiatif masyarakat dan menganut asas mandiri. Dalam pengelolaan Bumdes tujuan dari berdirinya lembaga bumdes yaitu meningkatkan perekonomian desa, meningkatkan pendapatan asli desa, meningkatkan pengelolaan potensi desa sesuai dengan kebutuhan masyarakat, menjadi tulang punggung pertumbuhan ekonomi perdesaan. 
Untuk mencapai kebutuhan bumdes dibutuhkan pengelolaan bumdes sebagai lembaga peningkatan ekonomi desa, untuk mencapai tujuan dari bumdes tersebut. Program bumdes tepule merupakan program untuk meningkatkatkan pembangunan masyaraskat desa khususnya meningkatkan perekonomian desa tudungano.

Bumdes Tepule dalam pengelolaannyauntuk meningkatkan perekonmian desa Tudungano telah melakukan berbagai cara kinerja yaitu dengan memanfaatkan sumber daya alam yang ada didesa Tudungano atau potensi Desa Tudungano. Potensi desa Tudungano salah satunya adalah melimpahnya sumber daya alam yaitu batu gunung, dimana bumdes Tepule melihat potensi tersebut dengan membuka unit usaha Bumdes Tepule yaitu penambangan batu gunung. Tidak hanya itu dalam pengelolaannya Bumdes Tepule juga membuka unit usaha baru, yang tidak hanya bertompa pada satu unit usaha saja. Unit usaha yang dibuka oleh bumdes Tepule ini yaitu penyewaan barang berupa kursi dimana dengan membuka unit usaha penyewaan barang tersebut akan menambah pendapatan Bumdes Tepule dari keuntungan sewa barang tersebut. Dalam mejalankan kinerjanya pengurus Bumdes Tepule juga meminimalisir pengurus bumdes Tepule dengan cara tidak mengangkat kepala unit dari unit-unit usaha Bumdes Tepule. Bumdes Tepule hanya memiliki 3 (tiga) pengurus Bumdes Tepule dengan tujuan meminimalisir bagi hasil dari keuntungan tersebut.

Pengurus Bumdes Tepule dalam pengelolaannya untuk meningkatkan perekonomian Desa Tudungano telah dilaksakan dengan keamampuan yang dimiliki oleh pengurus Bumdes Tepule dengan membuka unit-unit usaha Bumdes Tepule dengan tujuan peningkatan pendapatan Bumdes Tepule dan perekonomian masyarakat Desa Tudungano.

\section{Faktor Penghambat Yang dihadapi Bumdes Tepule Dalam pengelolaannya}

Tidak dapat dipungkiri bahwa pelaksaan tugas pokok dan pengelolaan Bumdes dalam meningkatkan perekonomian desa tidak selalu berjalan dengan lancar. Berdasarkan data yang diperoleh dilapangan melalui observasi dan wawancara dan dilengkapi dengan dokumentasi ada beberapa faktor yang menjadi penghambat dari kinerja Pengurus Bumdes tepule Dalam Menjalankan perannya dalam meningkatkan perekonomia desa yaitu :

1. Pola Komunikasi

Pola komunikasi sangat mempengaruhi berjalannya peran Bumdes dalam meningkatkan perekonomian desa dengan melihat bagimana hubungan emosional antara ketua Bumdes dengan anggotanya, ketua Bumdes dengan penasehat Bumdes, dapat dilihat dengan pola komunikasi yang dilihat selama ini. Melihat fakta yang terjadi di lapangan salah satu faktor penghambat bumdes ini dalam pengelolaannya yaitu pola komunikasi yang tidak berjalan dengan semestinya, baik antara ketua dan anggotanya maupun antara ketua dan penasehat Bumdes.

2. Tidak Memahami peran

Anggota Bumdes tidak memahami perannya sebagai pengurus Bumdes berdasarkan peraturan yang berlaku.Salah satu faktor penghambat Bumdes dalam pengelolaan bumdes yaitu pengurus Bumdes tidak memahami perannya sendiri.Fakta yang ditemukan dilapangan bahwa ternyata bahwa pengurus Bumdes tidak memahami 
perannya berdasarkan peraturan perundang-undangan dan peraturan desa atau anggaran dasar dan anggaran rumah tangga Bumdes Tepule.

3. Tidak Melibatkan Masyarakat

Dalam menjalankan program kerja seharusnya Bumdes selalu melibatkan masyarakat selaku objek dari Bumdes ini, akan tetapi fakta yang ditemukan dilapangan bahwa mulai dari berdirinya Badan Usaha Milik desa Bumdes Tepule ini tidak melibatkan masyarakat, yang seharusnya sebelum mejalankan program kerja harus ada kegiatan musyawarah desa. Terbukti dalam musyawarah bumdes Tepule baik dalam awal pembentukannya maupun sampai pembahasan program kerja Bumdes Tepule yang seharusnya melibatkan masyarakat selaku objek dari Bumdes Tepule hanya hal tersebut tidak dilakukan oleh pengurus Budes tepule. Dengan hal tersebut bahwa Bumdes Tepule tidak melibatkan manyarakat pada umumnya baik dalam persiapan menjalankan program maupun dalam pelaksanaan program kerja Bumdes.

4. Kurangnya sumber daya manusia

Dalam pengelolaan Bumdes pengurus tidak cukup hanya memiliki modal yang memumpuni akan tetapi harus mempunyai sumber daya manusia yang baik, agar usaha yang dibuat dapat tepat sasaran sesui dengan tujuan awal berdirinya bumdes Tepule, akan tetapi dapat ditemukan fakta bahwa pengurus Badan usaha Milik Desa Tudungano ini, tidak memiliki Sumber daya manusia yang baik terbukti semenjak berdirinya Bumdes ini pada tahun 2016 sampai saat peneliti melakukan penelitian dilapangan belum adanya hasil atau pendapatan yang dimiliki oleh Bumdes Tepule ini. Dengan demikian program bumdes Tepule belum berjalan dengan baik karna pada awalnya pengurus Bumdes ini tidak memikirkan dengan baik progam bumdes terutma sektor pemasaran hasil pengolahan batu yang dijalankan oleh Bumdes Tepule ini.

5. Tidak transparan (keterbukaan)

Dalam pengelolaan uang Negara diperlukan asas keterbukaan terhadap masyarakat tentang Bumdes baik itu kinerja maupun keuangan Bumdes itu sendiri. Dalam hal ini Bumdes Tepule seharusnya melakukan hal yang sama. Akan tetapi peneliti mendapatkan fakta bahwa transparansi anggaran tidak dilakukan oleh pengurus Bumdes dibuktikan selama Bumdes didirikan pada tahun 2016 sampai tahun 2018 Bumdes Tepule ini belum pernah melakukan pembuatan laporan keuangan Bumdes baik itu laporan triwulan, semester, maupun laporan tahunan. Dengan demikian Bumdes Tepule tidak melakukan transparansi anggaran terhadap masyarakat maupun unsure pemerintah dan ini yang menjadi salah satu penghambat Bumdes untuk meningkatkan perekonomian desa Tudungano.

\section{Upaya Yang Dilakukan Bumdes Tepule dalam mengatasi hambatan}

Badan usaha milik desa mempunyai andil besar dalam desa terutama dalam kesejahteraan masyarakat, yang diharapkan mampu meningkatkan taraf hidup masyarakat yang lebih baik.Pada kususnya memberikan pendapatan desa diluar dari Dana alokasi umum yang diberikan oleh pihak pemerintah pusat lewat Dana Desa (DD), maupun dari pemerintah daerah kabupaten lewat Alokasi Dana Desa (ADD).

Bumdes dalam pengelolaannya tidak selalu berjalan dengan baik, Bumdes dapat mengalami kerugian berupa tidak mendapatkan Laba usaha, bahkan mengalami 
kerugian.dan kemungkinan terburuknya modal Bumdes di lakukan penggelapan. Akan tetapi untuk mencapai Tujuan awal dari berdirinya Bumdes tidak hnya fakum terhadap kerugian yang dialami, akan tetapi adanya upaya-upaya yang dilakukan dari pihak Bumdes, masyarakat, maupun pihak pemerintah desa.

Mengenai hal tersebut upaya-upaya yang dilakukan untuk Bumdes Tepule ini dalam pengelolaannya didesa Tudungano yaitu :

1. Pergantian Pengurus Bumdes Tepule

Upaya ini adalah upaya yang dilakukan oleh pihak pemerintah desa Tudungano bersama masyarakat untuk menyelamatkan lembaga ini yang dianggap gagal dalampengelolaannya dan diharapkan dengan kepengurusan Bumdes yang baru akan membuat pola komunikasi yang baik. Mengenai hal tersebut pemerintah desa Tudungano bersama Masyarakat Tudungano saat melakukan MUSDES (musyawarah desa) tahun anggaran 2019, pada tanggal 2 oktober 2018 telah melakukan pemilihan pengurus Bumdes secara demokrasi atau pemilihan langsung yang dipilih oleh masyarakat desa Tudungano.

Dengan demikian pemerintah Desa Tudungano bersama Masyarakat desa Tudungano masih berharap bahwa Bumdes Mampu mengelola dengan baik Bumdes Tepule di desa Tudungano.

2. Melakukan Pelatihan Bagi Pengurus Bumdes

Pelatihan adalah salah satu upaya meningkatkan sumber daya manusia, atau keahlian yang dimiliki dapat diasah dengan melakukan pelatihan. Begitupun yang dilakukan pemerintah Desa dalam meningkatkan sumber daya manusia yang dimiliki oleh pengurus Bumdes Tepule ini dengan Harapan dapat menjalankan program kerja dengan baik.

3. Pengawasan

Pengawasan dilakukan oleh lembaga pengawas Bumdes yang telah dibentuk, oleh pemerintah desa Tudungano Bersama masyarakat lewat musyawarah Desa yang yang dihadiri oleh pihak kecamatan dan dari pihak kabupaten (DPMD).Berdasarkan anggaran dasar dan anggaran rumah tangga Bumdes Tepule.Langkah ini dilakukan untuk mengantisipasi terjadinya penyelewengan atau tidak berjalanya lembaga Bumdes sesuai dengan yang telah diatur oleh anggaran dasar dan anggaran rumah tangga Bumdes Tepule. Tidak hanya itu pengawasan pula dilakukan oleh unsur masyarakat, yang dapat melihat apa yang terjadi terhadap Bumdes Tepule dalam menjalankan program-program kerjanya. Upaya-upaya ini dilakukan semata-mata masyarakat mengharapkan Bumdes masih dapat menjalankan peranya dalam meningkatkan perekonomian Desa Tudungano.

4. Penambahan Modal Bumdes Tepule

Penambahan Modal Bumdes Tepule dilakukan oleh pihak pemerintah Desa Tudungano, sebesar Rp.140.000.000 (seratus empat puluh juta rupiah) untuk tahun anggaran 2019 lewat MUSDES yang dilakukan Pemerintah desa, bersama unsur BPD dan masyarakat pada tanggal 2 oktober 2018 dengan hasil keputusan bersama untuk melakukan penambahan modal Bumdes Tepule ini. Sumber anggaran untuk penambahan modal ini bersumber dari pemerintah Pusat lewat dana alokasi umum yaitu dana desa (DD). 
Dengan demikian upaya-upaya yang dilakukan Pemerintah Desa Bersama masyarakat desa Tudungano untuk mengatasi permasalahan yang dihadapi oleh lembaga Bumdes Tepule ini Dalam meningkatkan perekonomian di Desa Tudungano telah di ditempuh.Mulai dari penambahan modal sampai dengan pengawasan dilakukan oleh masyarakat Desa Tudungano.Hal tersebut adalah upaya terbaik yang dilakukan pemerintah Desa Tudungano Bersama Masyarakat desa Tudungano.

\section{PENUTUP}

\section{Kesimpulan}

bahwa:

Berdasarkan uraian pembahasan dalam penelitian ini, maka dapat disimpulkan

1. Pengelolaan Bumdes Tepule telah dilakukan semaksimal mungkin dengan membuka unit usaha Bumdes sesuai dengan potensi Desa Tudungano, dan meminimalisir pengurus Bumdes Tepule serta lebih pro aktif atau turun lapangan kerja dalam menjalankan kinerjanya.

2. Faktor-faktor penghambat yang dihadapi Bumdes dalam pengelolaannya di desa Tudungano yaitu mulai dari tidak adanya musyawarah desa atau tidak melibatkan masyarakat Desa Tudungano, sumber manusia yang dimiliki oleh pengurus Bumdes yang masih sangat kurang, komunikasi yang kurang baik atau terjadinya miskomunikasi antara pengurus bumdes dengan penasehat bumdes, dan pengelolaan Bumdes Tepule yang tidak transparan.

3. Upaya yang dilakukan Bumdes Tepule untuk mengatsasi hambatan, upaya yang telah ditempuh yaitu pergantian pengurus Bumdes yang diharapkan lebih baik melakukan pelatihan-pelatihan untuk pengurus Bumdes Tepule untuk meningkatkan sumber daya manusia, dan melakukan pengawasan terhadap Bumdes Tepule dengan membentuk pengawas Bumdes Tepule dan melibatkan masyarakat sebagai pengawas Bumdes Tepule, penambahan modal bumdes tepule.

\section{Saran}

1. Diharapkan kepada pihak pemerintah Desa Tudungano Kecamatan Sawa Kabupaten Konawe utara, Bersama masyarakat agar dalam memilih pengurus Bumdes agar lebih selektif berdasarkan asas kepantasan dan kepatuan, agar bumdes kedepanya lebih baik.

2. Kepada pengurus Bumdes agar lebih memilih unit usaha sesuai dengan potensi yang dimiliki oleh Desa Tudungano.

\section{Daftar Pustaka}

Ferdianto, benny. 2016. Eksistensibadan usaha milik desa terhadap peningkatan pendapatan asli desa di tiyuh candra kencana kecamatan tulang bawang tengah kabupaten tulang bawang barat mahasiswa fakultas hukum, universitas lampung

Kurniawan, ade eka. 2016. Peranan Badan Usaha Milik Desa dalam meningkatkan pendapatan asli Desa Mahasiswa Program Studi Ilmu Pemerintahan ,Fakultas Ilmu Sosial dan Ilmu Politik, Universitas Maritim Raja Alihaji. 
Noviratullah, 2018. Eksistensi badan usaha milik desa (bumdes) dalam meningkatkan perekonomian masyrakat desa soki kiecamatan belo kabupaten bima, mahasiswa program studi pendidikan ilmu pengetahuan sosial, jurusan pendidikan pengetahuan sosial, fakultas tarbiyah, universitas negeri maulana milik ibrahim

Peraturan Mentri Dalam Negeri No 39 tahun 2010 tentang badan usaha milik desa.

Samadi, Arrafiqur Rahman, Afrizal, 2018. Peranan Badan Usaha Milik Desa( Bumdes) Dalam Peningkatan Ekonomi Masyarakat ( Studi Pada Bumdes Desa Pekan Tebih Kecamatan Kepenuhan Hulu Kabupaten Rokan Hulu .Universitas Sumatera Utara Fakultas Ilmu Sosial dan Ilmu Politik Tesis Magister (Studi Pembangunan).

Undang-Undang Republik Indonesia No. 6 Tahun 2014 Tentang Desa

Undang-Undang Republik Indonesia Nomor 23 Tahun 2014 tentang Pemerintahan Daerah

Wiwin. 2017.Peran badan permusyawaratan desa dalam pembangunan di desa salassae kecamatan bulukumpa kabupten bulukumba Mahasiswa Program Studi Ilmu Pemerintahan, Fakultas Ilmu Sosial dan Ilmu Politik, Universitas Hasanuddin 